\title{
Phytoplankton structure is more influenced by nutrient enrichment than by temperature increase: an experimental approach upon the global changes in a shallow subtropical lake
}

\author{
Andressa da Rosa Wieliczko ${ }^{1,2, *}$ Lucia Ribeiro Rodrigues ${ }^{1}$, David da Motta-Marques ${ }^{1}$ and \\ Luciane Oliveira Crossetti ${ }^{3}$
}

${ }^{1}$ Instituto de Pesquisas Hidráulicas; Universidade Federal do Rio Grande do Sul, Universidade Federal do Rio Grande do Sul, Caixa Postal 15029, 91501-970, Porto Alegre, RS, Brazil.

2 Universidade do Vale do Rio dos Sinos, Av. Unisinos 950, Cristo Rei, 93022-000, São Leopoldo, RS, Brazil.

${ }^{3}$ Departamento de Ecologia, Instituto de Biociências, Av. Bento Gonçalves 9500, Agronomia, 91501-970, Porto Alegre, RS, Brazil.

* Corresponding author: andressarw@yahoo.com.br

Received: 29/10/18 Accepted: 02/09/19

\begin{abstract}
Phytoplankton structure is more influenced by nutrient enrichment than by temperature increase: An experimental approach upon the global changes in a shallow subtropical lake

Climate change is considered one of the greatest threats to aquatic ecosystems around the globe. Among the expected changes, including the dynamics of phytoplankton, the growth of cyanobacteria is often cited. This study evaluated the individual and combined effects of increased temperature and nutrients on phytoplankton community structure in a large, oligo-mesotrophic subtropical shallow lake (Mangueira Lake, southern Brazil). The study was conducted in microcosms to simulate possible scenarios of climate change, alone and in combination with nutrient enrichment ( $\mathrm{N}$ and $\mathrm{P})$; water samples were collected in winter and summer. Phytoplankton total biomass, species richness and diversity did not vary significantly with manipulation of temperature alone, either in winter or in summer. Only cyanobacteria biomass increased significantly with an increase in temperature, in the winter experiments. In summer, phytoplankton total biomass, species richness, Bacillariophyceae and Cyanobacteria increased significantly with enrichment of $\mathrm{N}$ and $\mathrm{P}$. The interaction between temperature increase and nutrient addition did not significantly affect phytoplankton attributes. Temperature increase alone was not sufficient to cause structural changes in the phytoplankton community. Instead, nutrient addition ( $\mathrm{N}$ and $\mathrm{P}$ ) proved to be the most significant influence on most phytoplankton attributes, even though turnover of bloom-forming cyanobacteria was not observed. Further studies on the resilience of aquatic ecosystems to climate changes may contribute to the conservation and management of these environments.
\end{abstract}

Key words: climate change, cyanobacteria, diversity, microcosms, resilience, lentic ecosystem

\section{RESUMO}

A estrutura do fitoplâncton é mais influenciada pelo enriquecimento de nutrientes do que pelo aumento de temperatura: uma abordagem experimental sobre as mudanças globais em um lago raso subtropical

A mudança climática é considerada uma das maiores ameaças aos ecossistemas aquáticos em todo o mundo. Entre as mudanças esperadas, incluindo a dinâmica do fitoplâncton, o crescimento de cianobactérias está entre os mais citados. O objetivo deste estudo foi avaliar os efeitos isolados e combinados do aumento de temperatura e nutrientes na estrutura da comunidade fitoplanctônica em um grande lago raso subtropical oligo-mesotrófico (Lagoa Mangueira, sul do Brasil). O estudo foi realizado em microcosmos para simular possíveis cenários de mudança climáticas, sozinhos e em combinação com enriquecimento de nutrientes ( $N$ e P), a partir de amostras de inverno e verão. Em ambas estações, a biomassa total do fitoplâncton, a riqueza e diversidade de espécies não variaram significativamente sob a manipulação isolada da temperatura. O aumento da temperatura elevou significativamente a biomassa de cianobactérias em experimentos de inverno. No verão, a biomassa total do 
fitoplâncton, a riqueza de espécies, Bacillariophyceae e Cyanobacteria aumentaram significativamente sob o enriquecimento de Ne P. A interação entre aumento de temperatura e adição de nutrientes não promoveu efeito significativo sobre os atributos fitoplanctônicos estudados. O aumento isolado da temperatura não foi forte o suficiente para promover mudanças estruturais na comunidade fitoplanctônica. Entretanto, a adição de nutrientes ( $N$ e P) demonstrou influenciar mais significativamente na maioria dos atributos do fitoplâncton, embora não tenha sido observado o recrutamento de cianobactérias formadoras de florações. Nesse sentido, mais estudos enfatizando a resiliência dos ecossistemas aquáticos quanto às mudanças climáticas podem contribuir para a conservação e manejo desses ambientes.

Palavras chave: mudança climática, cianobactérias, diversidade, microcosmos, resiliência, ecossistemas lênticos

\section{INTRODUCTION}

One of the most serious threats to natural ecosystems is climate change, due to its implications for the structure, function, and ecosystem services provided by lakes (ACIA, 2004; Rosenzweig et al., 2007; Havens \& Jeppesen, 2018). Monitoring and understanding the effects of climate change are ongoing challenges, as is predicting the many consequences that climate change may cause in different ecosystems (Adrian et al., 2009; Havens \& Jeppesen, 2018). Indeed, the Intergovernmental Panel on Climate Change (IPCC, 2007) estimated that the mean temperature of the atmosphere increased by $0.6{ }^{\circ} \mathrm{C}$ during the twentieth century.

Freshwater ecosystems are particularly vulnerable to climate changes because they are relatively isolated and fragmented physically within large terrestrial landscapes (Woodward et al., 2010). Eutrophication processes and increased temperature might affect the structure and function of lakes and ponds (Carvalho \& Kirika, 2003; Gomes et al., 2017). Some studies have examined the different aspects of intensifying global eutrophication (Pasternak et al., 2009), but little is known about the actual effects that this interaction (temperature and eutrophication) may cause in aquatic ecosystems (Carvalho \& Kirika, 2003).

Attempts to predict the possible effects of global climate change in temperate aquatic environments have involved experimentation (Davis et al., 2009; Feuchtmayr et al., 2010) and the use of modeling (Domis et al., 2007; Elliott \& Defew, 2011). However, the drivers of climate change will have varied effects on lakes, depending on the geographical location, altitude, morphometry, climate, vegetation and land use (Adrian et al.,
2009; Deng et al., 2016; Gomes et al., 2017). In agricultural catchments, for example, changes in precipitation and organic-matter decomposition may alter mainly the import of nutrients into water bodies (Adrian et al., 2009). On the other hand, during dry periods, increased residence time and nutrient loads are expected, favoring the occurrence of potentially toxic cyanobacteria (Jöhnk et al., 2008; Paerl \& Huisman, 2009; Moss, 2011; Newcombe et al., 2012).

Knowledge of the ecology of phytoplankton is a valuable tool for investigating the effects of environmental changes, with results that are applicable to other communities (Reynolds, 1998). Moreover, phytoplankton is an important biological element in the concept of the Water Framework Directive, for the evaluation of lakes, transitional waters and coastal waters (EC Parliament and Council, 2000). Considering the effects of global warming on the phytoplankton, such as increases in total biomass and shifts in the timing and magnitude of spring blooms (Jeppesen et al., 2009), growth of cyanobacteria is among the most frequently cited events (Havens et al., 2016; Richardson et al., 2019). Although many studies have shown higher growth rates and abundance of cyanobacteria as responses to climate change (Weyhenmeyer et al., 2002; Paerl \& Huisman, 2008; Adrian et al., 2009; Kosten et al., 2012; Domis et al., 2013; Beaver et al., 2018), other studies have shown that in non-stratified shallow lakes, dominated by macrophytes, the recruitment of cyanobacteria may not occur as expected (Moss et al., 2003; Fragoso et al., 2011). More-recent studies have demonstrated that warmer climates may, in fact, favor cyanobacterial development in shallow lakes (Kosten et al., 2012; Guo et al., 2019); and indeed, that changes 
in variables related to climate conditions, such as rainfall regime, may alter lake characteristics such as retention time and water stability, favoring cyanobacterial dominance, particularly in subtropical lakes (Ribeiro et al., 2012; Fuentes \& Petrucio, 2015; Havens et al., 2019).

Studying the dynamics of phytoplankton and the effects of temperature increase along with the eutrophication process is essential to initiate the development and planning of management strate- gies and restoration (Carvalho \& Kirika, 2003) of aquatic ecosystems in response to environmental changes. The hypothesis of this study was that the phytoplankton structure might be altered due to variations in temperature (warming) and nutrient concentrations (eutrophication)? Thus, the overall objective of this study was to evaluate the combined effect of temperature and addition of nutrients ( $\mathrm{N}$ and $\mathrm{P}$ ) on the phytoplankton community structure in a large shallow polymictic lake

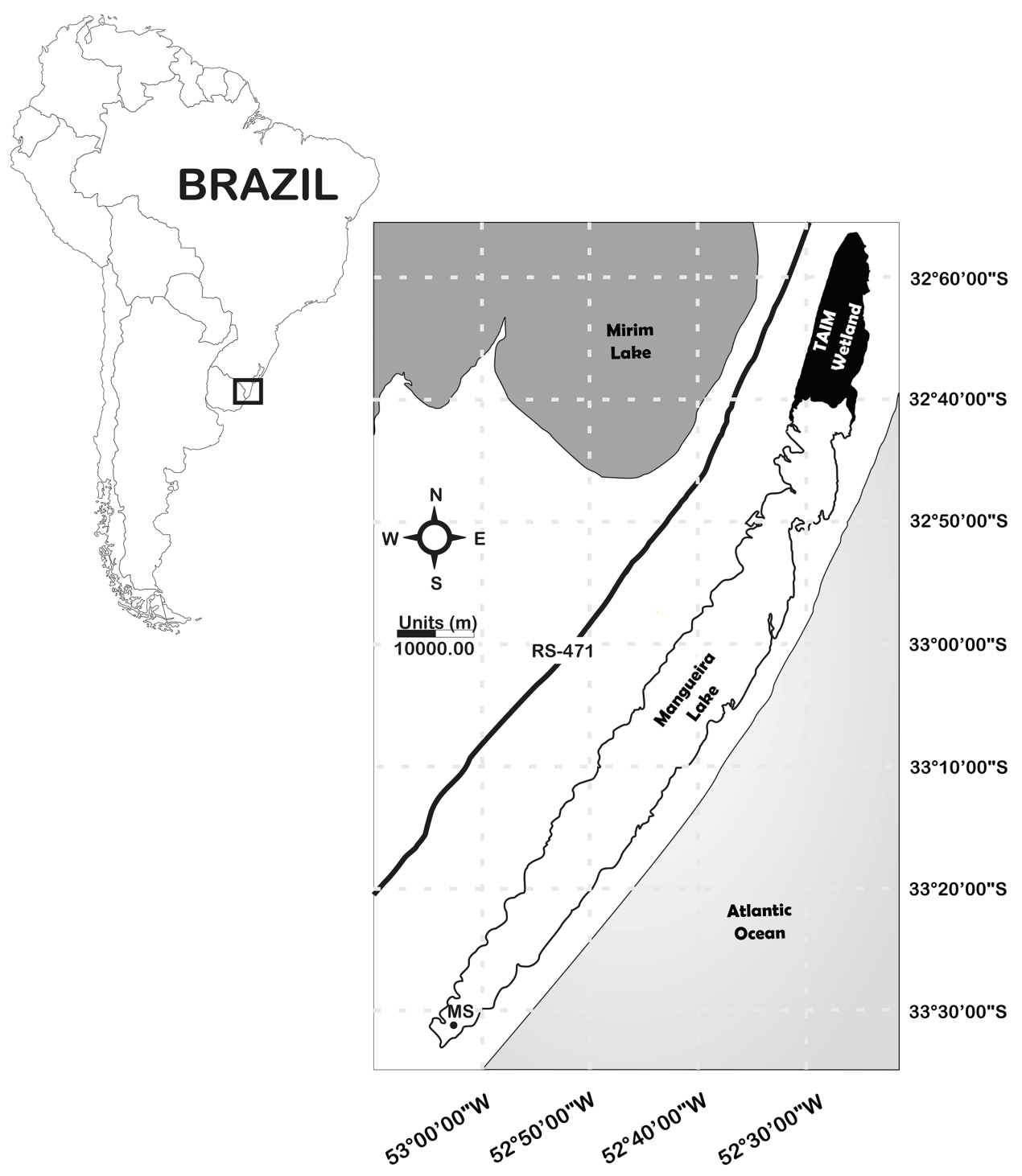

Figure 1. Location of Lake Mangueira, state of Rio Grande do Sul, Brazil. Black circle indicates the sampling point. MS = Southern Lake Mangueira. Localização da Lagoa Mangueira, Estado do Rio Grande do Sul, Brasil. Circulo preto indica o ponto de coleta no sul do lago. MS = Sul da Lagoa Mangueira. 
(Lake Mangueira, southern Brazil), in an in-situ experimental approach.

\section{MATERIALS AND METHODS}

\section{Study area}

Lake Mangueira is an oligo-mesotrophic shallow coastal lake (Crossetti et al., 2013) (Zmean $=3 \mathrm{~m}$; $\mathrm{Zmax}=9 \mathrm{~m}), 90 \mathrm{~km}$ long and 3-10 km wide, located in the southern part of the state of Rio Grande do Sul $\left(32^{\circ} 20^{\prime}\right.$ and $33^{\circ} 00^{\prime} \mathrm{S}$, and $52^{\circ} 20^{\prime}$ and $52^{\circ} 45^{\prime} \mathrm{W}$ ), southern Brazil (Fig. 1). The region has a subtropical climate (type Cfa; Kottek et al., 2006). The lake is drained periodically to irrigate rice fields, which determines its hydroperiod, comprised of low-water (generally in summer) and high-water (generally in winter) periods. The lake is continuous warm polymictic (no seasonal ice cover, stratifying at most a few hours at a time) (Lewis, 1983), with daily mixing due to intense wind action. The lake is connected to wetlands in the north, forming the Taim Hydrological System (THS), a federal conservation unit; in the south, large areas are covered with submerged, free-floating and emergent macrophytes (Rodrigues et al., 2015).

\section{Experimental design}

Water was collected in the pelagic zone (at the sub-surface) of southern Lake Mangueira and placed in barrels, aerated, and taken to the laboratory for an immediate start of the experiment. The individual and combined effects of temperature and nutrient addition were tested. The experimental enrichment consisted of four treatments: control (C), without nutrient addition; addition of phosphorus (P) $\left(\mathrm{KH}_{2} \mathrm{PO}_{4}\right.$, Merck $\left.\mathrm{PA}^{\circledR}\right)$; addition of nitrogen $(\mathrm{N})\left(\mathrm{NH}_{4} \mathrm{NO}_{3}\right.$, Merck); or combined addition of nitrogen and phosphorus ( $\mathrm{N}$ and $\mathrm{P}$ ). The amounts of nutrients added were based on a calculation of four times the mean concentration of orthophosphate and nitrate in the lake in the last five years (historical means $0.13 \mathrm{mgN} / \mathrm{L}$ and $0.04 \mathrm{mgP} / \mathrm{L}$ ). The nutrients were added only on the first day of the experiment, simulating higher nutrient input as a side-effect of climate changes (e.g., input of allochthonous nutrients or feedback processes).

The water with these treatments was exposed to three scenarios with different temperatures, simulating the predictions of climate change for southern South America described by the IPCC (IPCC, 2007), for winter and summer, as follows:

Scenario 0: control treatment, performed by calculating the mean air temperature over the last five years in the lake area. For the experiment, the control temperatures were $13{ }^{\circ} \mathrm{C}$ and $24{ }^{\circ} \mathrm{C}$ in winter and summer, respectively.

Scenario 1: followed scenario A2 of the IPCC (2007), which predicts high greenhouse-gas emissions (if emissions continue to increase as in the past decades) on the planet by 2100 , when in southern South America a temperature increase of around $4{ }^{\circ} \mathrm{C}$ is expected. For the experiment, the temperatures used were $17^{\circ} \mathrm{C}$ in winter and $28^{\circ} \mathrm{C}$ in summer.

Scenario 2: extrapolation of temperature, simulating increases during heat waves of up to 7 ${ }^{\circ} \mathrm{C}$. For the experiment, the temperature was 20 ${ }^{\circ} \mathrm{C}$ in winter and $31{ }^{\circ} \mathrm{C}$ in summer.

The experiment was conducted in replicated $(\mathrm{n}=3)$ microcosms (1.5-L glass aquariums), in climate-controlled chambers (one chamber for each temperature). The water was stirred daily and the photoperiod was $12 / 12 \mathrm{~h}$. Each experiment lasted 12 days, during which five water samples were taken for analysis of biological and abiotic parameters (on days 1, 3, 6, 9 and 12). The experiments were conducted in the winter of 2011 and the summer of 2012.

At the end of the experiment, on day 12, the mean final concentrations of total nitrogen (TN) for treatment $\mathrm{N}$ were $0.12 \mathrm{mg} / \mathrm{L}$ in winter and $0.02 \mathrm{mg} / \mathrm{L}$ in summer. The mean total phosphorus (TP) concentrations at the end of the experiment were 1.03 in winter and $0.40 \mathrm{mg} / \mathrm{L}$ in summer. The mean TN and TP final concentrations in the $\mathrm{N}$ and $\mathrm{P}$ treatments were 0.07 and $1.02 \mathrm{mg} / \mathrm{L}$ in winter, respectively, and 0.02 and $0.54 \mathrm{mg} / \mathrm{L}$ in summer.

\section{Abiotic and biotic variables}

The abiotic variables analyzed were temperature, dissolved oxygen, $\mathrm{pH}$ (HACH HQd Field - HQ 40d multi HACH), nitrite, nitrate, orthophos- 
phate, total nitrogen and total phosphorus (Mackereth et al., 1989).

For phytoplankton quantitative analysis, water aliquots were taken from each microcosm and fixed with $1 \%$ acetic Lugol. Replicate samples were integrated before quantification (Utermöhl, 1958; Lund et al., 1958). Biomass $\left(\mathrm{mm}^{3} / \mathrm{L}\right)$ was estimated by species biovolume (Hillebrand et al., 1999). Species that contributed at least $4 \%$ of the total biomass were considered biological descriptors. Species richness was estimated based on the number of taxa and the diversity index (Shannon \& Weaver, 1964).

\section{Data analysis}

Descriptive statistical analysis was performed for both abiotic and biotic data. One-way blocking analysis of variance (ANOVA) was performed to evaluate the effect of warming (block factor) and nutrient addition on the structure of the phytoplankton community. In all significant cases, Tukey's HSD test was performed. The software used was SYSTAT version 12 (Systat Software).

\section{RESULTS}

Physical and chemical variables of each treatment did not vary significantly among the days of experiment (measured on days 1, 3, 6, 9 and
12), in each treatment. In winter, the mean concentration of total nitrogen was $0.07 \pm 0.05$ $\mathrm{mg} / \mathrm{L}$, total phosphorus $0.53 \pm 0.51 \mathrm{mg} / \mathrm{L}, \mathrm{pH}$ $8.43 \pm 0.35$ and dissolved oxygen $9.96 \pm 0.91$ $\mathrm{mg} / \mathrm{L}$. In summer, the mean concentration of total nitrogen was $0.02 \pm 0.01 \mathrm{mg} / \mathrm{L}$, total phosphorus $0.28 \pm 0.22 \mathrm{mg} / \mathrm{L}, \mathrm{pH} 8.40 \pm 0.31$ and dissolved oxygen $8.13 \pm 0.85 \mathrm{mg} / \mathrm{L}$.

One hundred two species were identified, distributed in seven classes of microalgae. In winter, class Chlorophyceae had the highest number of taxa, followed by Cyanobacteria and Bacillariophyceae, in all experimental conditions. In summer, Chlorophyceae and Cyanobacteria had similar numbers of taxa, followed by Bacillariophyceae. Regarding the effects of individual parameters, in winter, Cyanobacteria biomass increased significantly with the increase of temperature, and was highest at $20^{\circ} \mathrm{C}(\mathrm{F}=7.4 ; p$ $=0.002$; Fig. $2 \mathrm{~A}$ ). Total biomass also increased significantly with increasing temperature $(\mathrm{F}=$ $3.58 ; p=0.04 ;$ Fig. $4 \mathrm{~A}$ ). In summer, temperature manipulation did not result in significant variations in the biomass of the phytoplankton groups $(\mathrm{F}=0.3 ; p=0.75$; Fig. $2 \mathrm{~B})$. The species richness and diversity did not vary significantly with manipulation of temperature alone, either in winter nor in summer (Figs. 4 and 5; Table 1). Addition of nutrients did not result in significant changes during the winter experiment. Neverthe-
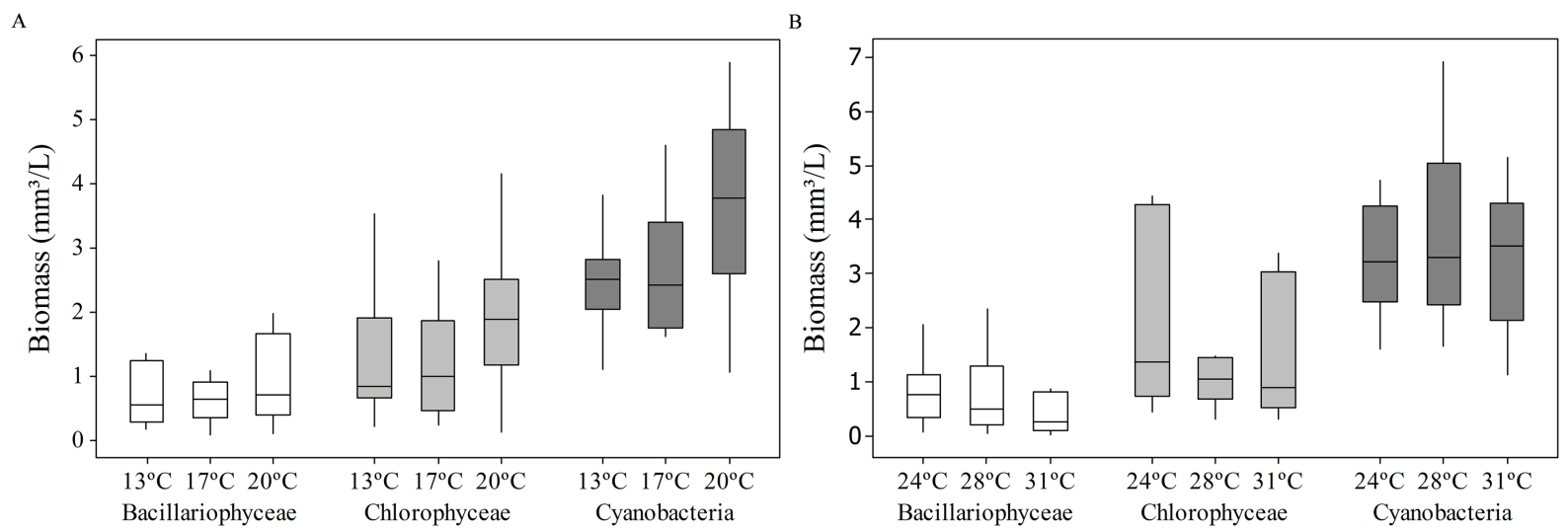

Figure 2. Boxplot (mean, interquartile ranges, $\mathrm{n}=20$ ) of Bacillariophyceae, Chlorophyceae and Cyanobacteria biomass in winter (13 ${ }^{\circ} \mathrm{C}, 17{ }^{\circ} \mathrm{C}, 21^{\circ} \mathrm{C}$; (A) and summer $\left(24^{\circ} \mathrm{C}, 28^{\circ} \mathrm{C}, 31^{\circ} \mathrm{C}\right)(\mathrm{B})$ experiments. Boxplot (mediana, intervalos interquartis, $\left.n=20\right)$ de biomassa de Bacillariophyceae, Chlorophyceae e Cyanobacteria nos experimentos de inverno $\left(13^{\circ} \mathrm{C}, 17^{\circ} \mathrm{C}, 21^{\circ} \mathrm{C}\right)(\mathrm{A})$ e verão $(24$ $\left.{ }^{\circ} \mathrm{C}, 28^{\circ} \mathrm{C}, 31^{\circ} \mathrm{C}\right)(\mathrm{B})$. 
Table 1. Relative biomass (\%) and total biomass contribution (\%) of the phytoplankton descriptor species in all the treatments (C $=$ control, $\mathrm{N}=\mathrm{N}$ addition, $\mathrm{P}=\mathrm{P}$ addition and $\mathrm{NP}=\mathrm{NP}$ addition), in winter $(\mathrm{A})$ and summer $(\mathrm{B})$. Biomassa relativa (\%) e contribuição total de biomassa (\%) das espécies descritoras do fitoplâncton em todos os tratamentos $(C=$ controle, $N=$ adição de $N, P$ $=$ adição de $P$ e $N P=$ adição de $N P)$, no inverno $(A)$ e verão $(B)$.

A

Species

$13^{\circ} \mathrm{C} \quad 17^{\circ} \mathrm{C} \quad 20^{\circ} \mathrm{C}$

Bacillariophyceae

Aulacoseira granulata (Ehr.) Simon.

Nitzschia palea (Kütz.) W.Smith

Nitzschia $\mathrm{sp.}$

Punctastriata sp.

\begin{tabular}{ccccccccccccc}
\multicolumn{1}{c}{$\mathbf{1 3}^{\circ} \mathbf{C}$} & \multicolumn{1}{c}{$\mathbf{1 7}^{\circ} \mathbf{C}$} & \multicolumn{1}{c}{$\mathbf{2 0}^{\circ} \mathbf{C}$} \\
\hline $\mathrm{C}$ & $\mathrm{N}$ & $\mathrm{P}$ & $\mathrm{NP}$ & $\mathrm{C}$ & $\mathrm{N}$ & $\mathrm{P}$ & $\mathrm{NP}$ & $\mathrm{C}$ & $\mathrm{N}$ & $\mathrm{P}$ & $\mathrm{NP}$ \\
\hline & & & & & & & & & & & \\
5.2 & 7.2 & 2.0 & 6.1 & 2.1 & 4.7 & 0.6 & 1.3 & 5.6 & 2.7 & 0.9 & 0.6 \\
2.2 & 0.6 & 0.7 & 6.8 & 0.3 & 0.2 & 0.6 & 3.1 & 0.4 & 0.8 & 0.1 & 11.6 \\
2.2 & 0.0 & 29.2 & 1.7 & 0.0 & 0.0 & 0.0 & 0.0 & 1.6 & 0.0 & 3.7 & 0.0 \\
2.3 & 1.4 & 1.0 & 1.8 & 5.2 & 4.4 & 6.3 & 15.3 & 7.3 & 3.2 & 2.9 & 1.9 \\
0.3 & 0.4 & 0.2 & 2.4 & 0.0 & 0.0 & 0.2 & 0.0 & 0.1 & 0.3 & 0.0 & 0.1 \\
\hline
\end{tabular}

Synedra sp.

\section{Chlorophyceae}

Botryococcus sp.

Coelastrum microporum Näg.

$\begin{array}{llllllllllll}14.0 & 8.4 & 6.2 & 3.8 & 1.7 & 6.8 & 2.3 & 4.3 & 2.2 & 10.0 & 4.8 & 0.0\end{array}$

Hariotina reticulata Dang.

Pseudopediastrum boryanum (Turp.) E.Hegewald

Scenedesmus ecornis (Ehr.) Chodat

$\begin{array}{llllllllllll}0.3 & 1.4 & 1.1 & 3.2 & 1.0 & 2.1 & 0.2 & 6.5 & 4.1 & 0.6 & 5.5 & 3.6\end{array}$

$\begin{array}{llllllllllll}1.7 & 9.1 & 9.6 & 0.0 & 8.4 & 0.0 & 3.3 & 1.0 & 0.0 & 1.5 & 0.0 & 2.6\end{array}$

Scenedesmus sp.

$\begin{array}{llllllllllll}1.7 & 2.5 & 1.9 & 2.3 & 1.4 & 1.8 & 4.2 & 2.1 & 1.6 & 2.0 & 3.0 & 1.7\end{array}$

$\begin{array}{llllllllllll}0.1 & 0.0 & 1.5 & 1.6 & 0.0 & 0.0 & 3.3 & 3.8 & 0.0 & 0.0 & 5.0 & 9.0\end{array}$

Cyanobacteria

Planktolyngbya contorta (Lemm.) Anag. et Kom.

$\begin{array}{llllllllllll}0.0 & 0.0 & 0.0 & 0.0 & 0.0 & 0.0 & 0.1 & 0.5 & 0.0 & 0.0 & 0.2 & 19.6\end{array}$

Planktolyngbya limnetica (Lemm.) Kom.-Leg. et Cron.

Pseudanabaena cf. limnetica (Lemm.) Kom.

Snowella lacustris (Chod.) Kom. et Hind.

$\begin{array}{llllllllllll}14.0 & 15.0 & 8.7 & 11.5 & 26.5 & 22.8 & 19.7 & 17.7 & 16.3 & 14.9 & 13.7 & 7.0\end{array}$

\section{Zygnemaphyceae}

Staurastrum cf. paradoxum Meyen ex Ralfs

$\begin{array}{llllllllllll}7.1 & 7.3 & 6.4 & 9.5 & 15.1 & 17.2 & 10.1 & 9.1 & 15.9 & 18.9 & 19.2 & 9.3\end{array}$

$\begin{array}{lllllllllllll}20.9 & 27.0 & 10.4 & 20.3 & 12.7 & 13.1 & 20.7 & 9.4 & 11.9 & 14.3 & 11.7 & 5.8\end{array}$

Total Biomass (\%)

\begin{tabular}{cccccccccccc}
3.5 & 1.0 & 4.0 & 1.3 & 4.4 & 1.0 & 2.6 & 1.6 & 2.1 & 3.1 & 6.5 & 0.8 \\
\hline 76.8 & 81.8 & 84.1 & 75.3 & 80.3 & 75.3 & 75.7 & 76.7 & 72.2 & 73.1 & 80.1 & 76.9
\end{tabular}

B

\begin{tabular}{lllllllllllll} 
& \multicolumn{4}{c}{$\mathbf{2 4}^{\circ} \mathbf{C}$} & & \multicolumn{4}{c}{$\mathbf{2 8}^{\circ} \mathbf{C}$} & & \multicolumn{3}{c}{$\mathbf{3 1}^{\circ} \mathrm{C}$} \\
\hline $\mathrm{C}$ & $\mathrm{N}$ & $\mathrm{P}$ & $\mathrm{NP}$ & $\mathrm{C}$ & $\mathrm{N}$ & $\mathrm{P}$ & $\mathrm{NP}$ & $\mathrm{C}$ & $\mathrm{N}$ & $\mathrm{P}$ & $\mathrm{NP}$ \\
\hline
\end{tabular}

Bacillariophyceae

Nitzschia palea (Kütz.) W. Smith

Nitzschia sp.

$\begin{array}{llllllllllll}0.0 & 0.5 & 0.2 & 10.0 & 0.4 & 0.5 & 0.1 & 12.9 & 0.4 & 0.8 & 0.8 & 9.9\end{array}$

Synedra sp.

$\begin{array}{llllllllllll}0.0 & 0.0 & 0.0 & 0.0 & 0.0 & 0.0 & 0.0 & 1.6 & 10.4 & 0.0 & 0.0 & 1.2\end{array}$

Ulnaria oxyrhynchus (Kütz.) Aboal

$\begin{array}{llllllllllll}0.7 & 0.8 & 0.0 & 7.7 & 0.4 & 0.9 & 0.3 & 2.7 & 0.0 & 0.2 & 0.3 & 0.1\end{array}$

\section{Chlorophyceae}

Botryococcus sp.

Coelastrum microporum Näg.

\begin{tabular}{llllllllllll}
9.8 & 17.8 & 3.1 & 5.4 & 11.5 & 12.3 & 3.5 & 3.0 & 2.3 & 3.2 & 3.7 & 1.1 \\
\hline
\end{tabular}

Hariotina reticulata Dang.

Monoraphidium contortum (Thuret) Kom.-Leg.

Mougeotia sp.

Scenedesmus sp.

\begin{tabular}{cccccccccccc}
5.7 & 0.0 & 0.0 & 0.7 & 9.8 & 0.0 & 0.0 & 1.0 & 0.0 & 0.0 & 0.0 & 1.4 \\
0.4 & 7.4 & 1.3 & 14.6 & 2.4 & 0.6 & 1.7 & 11.5 & 0.8 & 1.7 & 3.1 & 9.8 \\
0.0 & 4.8 & 0.0 & 4.8 & 0.0 & 5.6 & 0.0 & 5.6 & 0.0 & 0.0 & 1.1 & 0.0 \\
3.4 & 3.8 & 2.5 & 0.6 & 5.6 & 4.1 & 4.2 & 1.5 & 1.5 & 3.2 & 1.0 & 0.9 \\
37.9 & 0.0 & 28.6 & 23.5 & 0.0 & 28.0 & 0.0 & 0.0 & 36.0 & 0.0 & 0.0 & 24.9 \\
0.0 & 0.0 & 0.0 & 0.6 & 0.0 & 0.0 & 0.0 & 0.1 & 0.0 & 0.0 & 0.0 & 5.1 \\
\hline
\end{tabular}

Cyanobacteria

Planktolyngbya contorta (Lemm.) Anag. et Kom.

$\begin{array}{llllllllllll}7.5 & 6.2 & 11.3 & 0.9 & 3.1 & 5.0 & 12.9 & 1.5 & 4.3 & 7.0 & 2.3 & 0.4\end{array}$

Planktolyngbya limnetica (Lemm.) Kom.-Leg. et Cron.

$\begin{array}{llllllllllll}18.6 & 25.3 & 28.0 & 15.3 & 39.3 & 20.4 & 38.1 & 42.5 & 17.8 & 49.9 & 40.1 & 26.1\end{array}$

Pseudanabaena cf. limnetica (Lemm.) Kom.

$\begin{array}{llllllllllll}4.8 & 12.0 & 6.7 & 2.1 & 6.0 & 7.3 & 12.7 & 3.7 & 8.9 & 12.7 & 17.0 & 3.4\end{array}$

Snowella lacustris (Chod.) Kom. et Hind.

\begin{tabular}{llllllllllll}
0.0 & 0.0 & 0.0 & 1.4 & 1.6 & 0.2 & 0.5 & 0.1 & 0.3 & 0.0 & 0.5 & 0.0 \\
\hline
\end{tabular}

Total Biomass (\%)

\begin{tabular}{llllllllllll}
88.7 & 78.6 & 81.7 & 87.5 & 80.1 & 84.9 & 74.1 & 87.7 & 82.5 & 78.8 & 70.2 & 84.3 \\
\hline
\end{tabular}


less, the combined addition of $\mathrm{N}$ and $\mathrm{P}$ resulted in a significant increase in richness $(\mathrm{F}=9.34 ; p<$ 0.001 ; Fig. 5B), total biomass ( $\mathrm{F}=5.35 ; p<$ 0.005 ; Fig. 3B), biomass of Bacillariophyceae (F $=4.7 ; p=0.006$; Fig. 3B), Chlorophyceae $(\mathrm{F}=$ 3.55 ; $p=0.02$; Fig. 3B) and biomass of Cyanobacteria $(\mathrm{F}=2.9 ; p=0.04$; Fig. $3 \mathrm{~B})$ in the summer experiments.

The interaction between temperature increase and nutrient addition did not significantly affect the phytoplankton parameters evaluated. Twenty descriptor species were identified in all treatments (winter and summer), contributing about $81 \%$ of the total phytoplankton biomass. Despite the significant increase of Cyanobacteria biomass at $20^{\circ} \mathrm{C}$ in the winter experiments (Fig. 2A), the composition of the descriptor species did not change (Table 1A). The biomass of Planktolyngbya contorta, $P$. limnetica and Snowella lacustris increased slightly when the temperature and
A

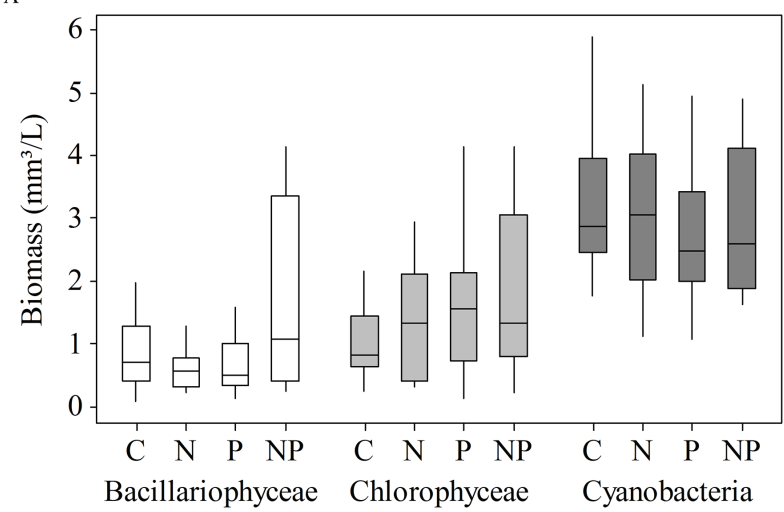

B

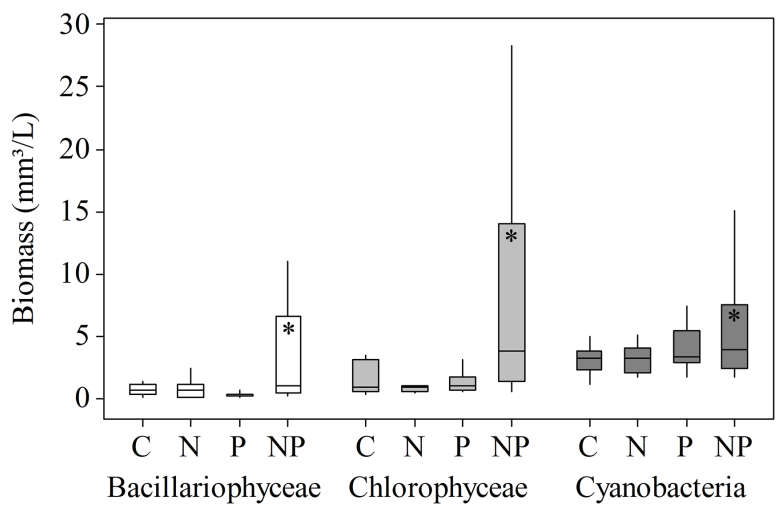

Figure 3. Boxplot (mean, interquartile ranges, $n=15$ ) of Bacillariophyceae, Chlorophyceae and Cyanobacteria biomass in the treatments with nutrient addition $(\mathrm{C}=$ control, $\mathrm{P}=\mathrm{P}$ addition, $\mathrm{N}=\mathrm{N}$ addition, $\mathrm{NP}=\mathrm{NP}$ addition), in winter $(\mathrm{A})$ and summer $(\mathrm{B})$ experiments. *significant difference from the other treatments. Boxplot (mediana, intervalos interquartis, $n=15$ ) da biomassa de Bacillariophyceae, Chlorophyceae e Cyanobacteria nos tratamentos com adição de nutrientes $(C=$ controle, $P=$ adição de $P, N=$ adição de $N, N P=$ adição de $N P)$, no inverno $(A)$ e no verão $(B)$. *diferença significativa dos outros tratamentos.
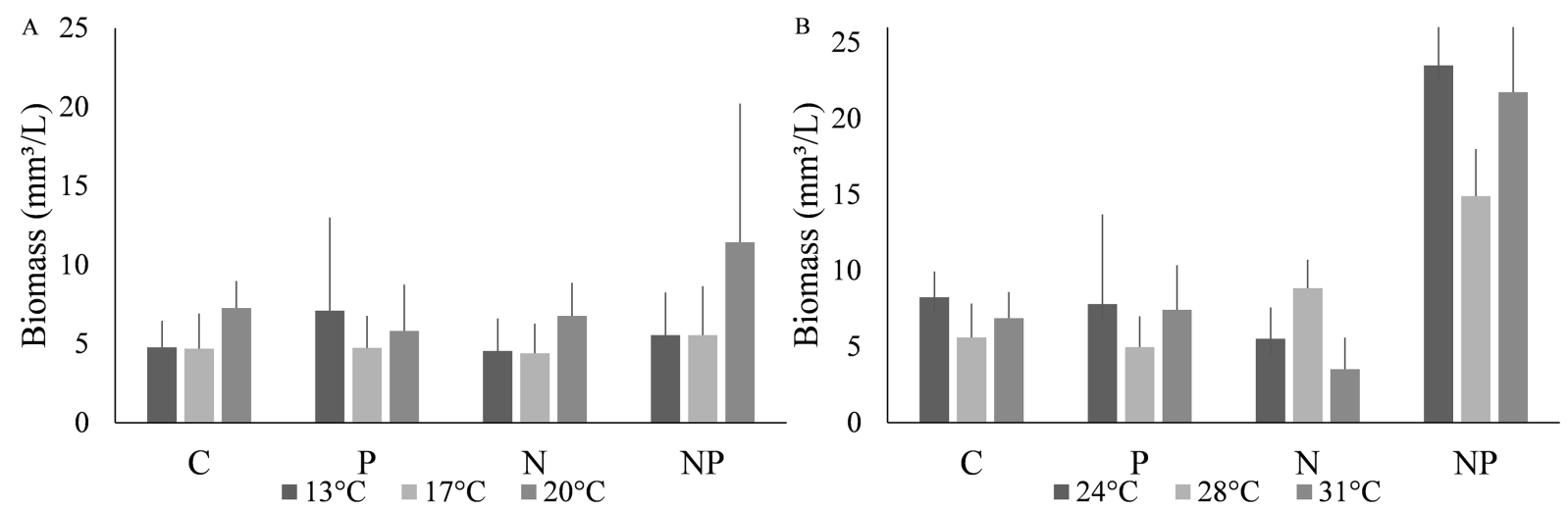

Figure 4. Effect of warming and nutrient enrichment on phytoplankton total biomass $\left(\mathrm{mm}^{3} / \mathrm{L}\right)$ in winter $\left(13^{\circ} \mathrm{C}, 17^{\circ} \mathrm{C}, 21^{\circ} \mathrm{C}\right)(\mathrm{A})$ and summer $\left(24^{\circ} \mathrm{C}, 28{ }^{\circ} \mathrm{C}, 31^{\circ} \mathrm{C}\right)(\mathrm{B})$ experiments, in all treatments $(\mathrm{C}=$ control, $\mathrm{P}=\mathrm{P}$ addition, $\mathrm{N}=\mathrm{N}$ addition, $\mathrm{NP}=\mathrm{NP}$ addition $)(\mathrm{n}=$ 5). Efeito do aquecimento e enriquecimento de nutrientes na biomassa total do fitoplâncton ( $\left.\mathrm{mm}^{3} / \mathrm{L}\right)$ nos experimentos de inverno $(13$ $\left.{ }^{\circ} \mathrm{C}, 17^{\circ} \mathrm{C}, 21^{\circ} \mathrm{C}\right)(\mathrm{A})$ e de verão $\left(24^{\circ} \mathrm{C}, 28^{\circ} \mathrm{C}, 31^{\circ} \mathrm{C}\right)(\mathrm{B})$, em todos os tratamentos $(\mathrm{C}=$ controle, $P=$ adição de $P, N=$ adição de $N$, $N P=\operatorname{adição~de~NP)~}(n=5)$. 
nutrients increased in the winter treatments. In the summer experiments, the descriptor species Nitzschia palea, Coelastrum microporum and Planktolyngbya limnetica mainly contributed to the significant increase in phytoplankton biomass in the $\mathrm{N}$ and or $\mathrm{P}$ enrichments (Table 1B),

\section{DISCUSSION}

The results showed that in Lake Mangueira, the combined nutrient addition ( $\mathrm{N}$ and $\mathrm{P}$ ) was more important in altering the phytoplankton parameters (total biomass, species richness, Bacillariophyceae, Chlorophyceae and Cyanobacteria biomasses) in summer than the temperature increase, which significantly increased the Cyanobacteria biomass in winter. The composition of the descriptor species remained similar following the manipulations. According to some authors, alterations in growth rates, abundance, and species composition of phytoplankton can be considered as indicators of climate changes (Adrian et al., 2009).

Among all the expected side effects of climate change, increasing temperature is one of the most worrying because it directly influences the metabolism of photosynthetic aquatic organisms, increasing their growth rates and biomass accumulation (Padilla-Gamiño \& Carpenter, 2007). In shallow lakes, cyanobacteria blooms have become more common due to the adaptability of this group to extreme conditions, especially in high temperatures (Paerl \& Huisman, 2008; Kosten et al., 2012; Winder \& Sommer, 2012; Beaver et al., 2018). This adaptability gives cyanobacteria a competitive advantage over other phytoplankton groups such as diatoms and green algae (Reynolds, 2006; Jöhnk et al., 2008). The results of the present study agreed with this statement only in the winter experiments, where the increase in temperature (from $13{ }^{\circ} \mathrm{C}$ to $20^{\circ} \mathrm{C}$ ) led to an increase in cyanobacterial biomass. Although the $\mathrm{N}$ and $\mathrm{P}$ enrichment also favored the abundance increase of cyanobacteria, in the summer experiments the composition of descriptor species did not change. This outcome contradicts our expectation that potentially bloom-forming species that were previously recorded in high abundance in this lake, such as Cylindrospermopsis raciborskii and Microcystis aeruginosa (Crossetti et al., 2014), would successfully develop under the experimental conditions; however, in this study both were recorded in low biomasses. The blue-green descriptors found in the present study (Planktolyngbya contorta, Pseudanabaena limnetica and Planktolyngbya limnetica) are usually related to turbid and mixed environments, being tolerant of low light intensities (Reynolds et al., 2002; Padisák et al., 2009).
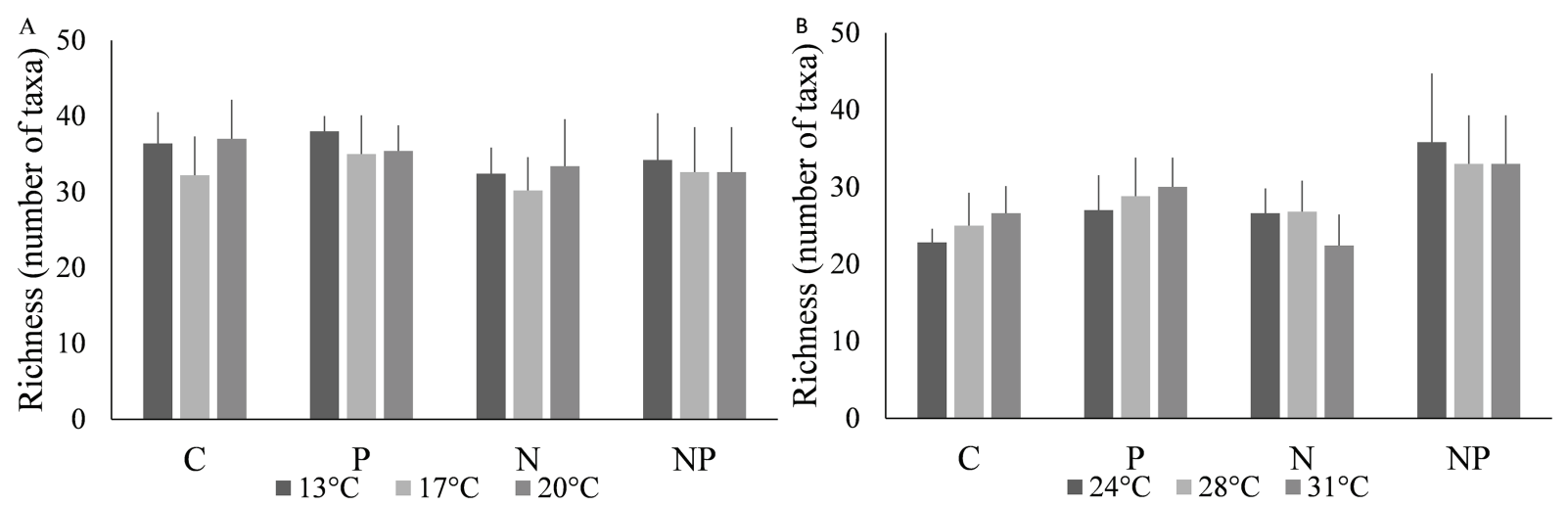

Figure 5. Effect of heating and nutrient enrichment on phytoplankton richness (number of taxa) in winter $\left(13^{\circ} \mathrm{C}, 17^{\circ} \mathrm{C}, 21^{\circ} \mathrm{C}\right)(\mathrm{A})$ and summer $\left(24^{\circ} \mathrm{C}, 28^{\circ} \mathrm{C}, 31^{\circ} \mathrm{C}\right)(\mathrm{B})$ experiments, in all treatments $(\mathrm{C}=$ control, $\mathrm{P}=\mathrm{P}$ addition, $\mathrm{N}=\mathrm{N}$ addition, $\mathrm{NP}=\mathrm{NP}$ addition $)$ $(\mathrm{n}=5)$. Efeito do aquecimento e enriquecimento de nutrientes na riqueza fitoplanctônica (número de taxa) nos experimento de inverno $\left(13{ }^{\circ} \mathrm{C}, 17^{\circ} \mathrm{C}\right.$ e $\left.21^{\circ} \mathrm{C}\right)(\mathrm{A})$ e de verão $\left(24^{\circ} \mathrm{C}, 28^{\circ} \mathrm{C}, 31^{\circ} \mathrm{C}\right)(\mathrm{B})$, em todos os tratamentos $(\mathrm{C}=$ controle, $P=$ adição de $P$, adição de $N$ $=N, N P=\operatorname{adição~de~} N P)(n=5)$. 
Although the vast majority of studies currently seek to demonstrate the drastic effects of global change on aquatic ecosystems and consequently on the structure and dynamics of phytoplankton (Elliott, 2011; Verdonschot et al., 2013; Beaver et al., 2018; Monchamp et al., 2018), some studies have shown that these environments will not always become cyanobacteria monocultures. Moss et al. (2003), in a nutrient-addition experiment conducted in mesocosms, found that a rise in temperature (over the year or only in the summer) did not significantly alter the levels of chlorophyll- $a$ or the biomass of phytoplankton. Indeed, the results suggesting that in non-stratified shallow lakes dominated by macrophytes, the feared blue-green dominance under global warming may not be as catastrophic as expected. Fragoso et al. (2011), through simulations in a model of ecological dynamics (HPI-TRIM3D-PCLake) in Lake Mangueira, found that the effects of climate change from increasing temperature (according to IPCC, scenario A2) and addition of nutrients (reaching eutrophic levels) were not significantly important for structuring the aquatic communities (phytoplankton, zooplankton, macrophytes, omnivorous and piscivorous fish). These authors showed that the highest nutrient loading negatively affected water transparency, although the changes were relatively small and slow, indicating high resilience of the system, or high inertia of the lake due to its large size.

Lake Mangueira is a large subtropical shallow lake which has been monitored since 2001. Studies of the high spatial and temporal variability of bacterioplankton (Lima et al., 2016), periphyton (Faria et al., 2015), phytoplankton (Crossetti et al., 2014; Freitas-Teixeira et al., 2016), zooplankton (Rosa et al., 2017) and fish (Rodrigues et al., 2014; 2015) have demonstrated that the intense hydrodynamics of Lake Mangueira, influenced by strong winds, is closely related to the structural patterns of these communities. Regime changes in lakes may be related to the inertia of these environments and the intrinsic variability of the ecosystem (Contamin \& Ellison, 2009), and should be considered in the context of the expected side effects of climate changes.

For decades, the world has faced the problem of eutrophication of aquatic systems, expanding scientific efforts aiming at understanding this process and the responses of phytoplankton to nutrient loading. Studies have shown that nitrogen, phosphorus, or the availability of both key nutrients controls phytoplankton growth rates (Smith et al., 1999; Elmgren \& Larsson, 2001), biomass (Cloern, 2001; Bledsoe et al., 2004) and species composition (Duarte et al., 2000; Smayda $\&$ Reynolds, 2001). From the point of view of global climate change, intensified eutrophication in shallow lakes is expected (Jeppesen et al., 2010; 2011), through both changes in mixing patterns, and altered water regimes that can generate discharges of nutrients from nonpoint sources (Winder \& Sommer, 2012). In this study, nutrient enrichment might be indirectly responsible for contributing to the increase in species richness and total phytoplankton, cyanobacteria and diatom biomass in the warm season (summer) regardless of temperature.

A decrease in phytoplankton diversity is also one of the expected effects of climate change, especially due to ecosystem physical and chemical changes and input of nutrients (Winder \& Sommer, 2012). In the Lake Mangueira experiment, significant changes in species richness were observed in summer and under $\mathrm{N}$ and $\mathrm{P}$ enrichment (Fig. 5B). Despite these changes, the diversity of species found in the experiments was not altered, indicating that this increase in species richness did not contribute to the total biomass observed.

\section{CONCLUSION}

In summary, the changes observed in the structure of phytoplankton indicated that the temperature increase alone, in accordance with the IPCC (2007) A2 scenario $\left(+4{ }^{\circ} \mathrm{C}\right)$ and an extreme increase of temperature $\left(+7^{\circ} \mathrm{C}\right)$, was not sufficient to cause structural changes. Addition of key nutrients ( $\mathrm{N}$ and $\mathrm{P}$ combined) proved to be the most significant influence on the phytoplankton parameters, even though turnover of bloom-forming cyanobacteria was not observed. The experimental manipulations in this study are far from representing the actual complexity of the interactions in Lake Mangueira. Further laboratory or in-situ studies are still necessary to enable predic- 
tions of the influence of global changes on each aquatic ecosystem. Studies emphasizing the resilience of aquatic ecosystems to climate changes may contribute to the conservation and management of these environments.

\section{ACKNOWLEDGEMENTS}

The authors thank the Conselho Nacional de Desenvolvimento Científico e Tecnológico (CNPq, process 555874/2010-9) of Brazil for financial support. The English text was revised by Dr. Janet Reid (JWR Associates).

\section{REFERENCES}

ACIA. 2004. Impacts of a Warming Artic: Artic Climate Impact Assessment. Cambridge University Press, New York.

ADRIAN, R., C. M. O. REILLY, H. ZAGARESE, S. B. BAINES, O. DAG, W. KELLER, D. M. LIVINGSTONE, R. SOMMARUGA \& D. STRAILE. 2009. Lakes as sentinels of climate change. Limnology and Oceanography, 54 (6): 2283-2297.

BEAVER, J. R., J. E. KIRSCH, C. E. TAUSZ, E. E. SAMPLES, T. R. RENICKER, K. C. SCOTESE, H. A. MCMASTER, B. J. BLASIUS-WERT, P. V. ZIMBA \& D. A. CASAMATTA. 2018. Long-term trends in seasonal plankton dynamics in Lake Mead (Nevada-Arizona, USA) and implications for climate change. Hydrobiologia, 822 (1): 85-109.

BLEDSOE, E. L., E. J. PHLIPS, C. E. JETT \& K. A. DONNELLY. 2004. The relationships among phytoplankton biomass, nutrient loading and hydrodynamics in an inner-shelf estuary. Ophelia, 58 (1): 29-47.

CARVALHO, L. \& A. KIRIKA. 2003. Changes in shallow lake functioning: response to climate change and nutrient reduction. Hydrobiologia, 506-509 (1-3): 789-796.

CLOERN, J. E. 2001. Our evolving conceptual model of the coastal eutrophication problem. Marine Ecology Progress Series, 210: 223-253.

CONTAMIN, R. \& A. M. ELLISON. 2009. Indicators of regime shifts in ecological systems: what do we need to know and when do we need to know it? Ecological applications: a publication of the Ecological Society of America, 19 (3): 799-816.

CROSSETTI, L. O., V. BECKER, L. de S. CARDOSO, L. R. RODRIGUES, L. S. DA COSTA \& D. DA MOTTA-MARQUES. 2013. Is phytoplankton functional classification a suitable tool to investigate spatial heterogeneity in a subtropical shallow lake? Limnologica, 43 (3): 157-163.

CROSSETTI, L. O., F. SCHNECK, L. M. FREITAS-TEIXEIRA \& D. da MOTTAMARQUES. 2014. The influence of environmental variables on spatial and temporal phytoplankton dissimilarity in a large shallow subtropical lake (Lake Mangueira, southern Brazil). Acta Limnologica Brasiliensia, 26 (2): 111-118.

DAVIS, T. W., D. L. BERRY, G. L. BOYER \& C. J. GOBLER. 2009. The effects of temperature and nutrients on the growth and dynamics of toxic and non-toxic strains of Microcystis during cyanobacteria blooms. Harmful Alga, 8 (5): 715-725.

DENG, J., B. QIN, J. SARVALA, N. SALMASO, G. ZHU, A. VENTELÄ, Y. ZHANG, G. GAO, L. NURMINEN, T. KIRKKALA, M. TARVAINEN \& K. VUORIO. 2016. Phytoplankton assemblages respond differently to climate warming and eutrophication: A case study from Pyhäjärvi and Taihu. Journal of Great Lakes Research, 42 (2): 386-396.

DING, Y., H. XU, J. DENG, B. QIN \& Y. HE. 2019. Impact of nutrient loading on phytoplankton: a mesocosm experiment in the eutrophic Lake Taihu, China. Hydrobiologia, 829 (1): 167-187.

DOMIS, L. S., W. M. MOOIJ \& J. HUISMAN. 2007. Climate-induced shifts in an experimental phytoplankton community: a mechanistic approach. Hydrobiologia, 584 (1): 403-413.

DOMIS, L. S., J. J. ELSER, A. S. GSELL, V. L. M. HUSZAR, B. W. IBELINGS, E. JEPPESEN, S. KOSTEN, W. M. MOOIJ, F. ROLAND, U. SOMMER, E. VAN DONK, M. WINDER \& M. LÜRLING. 2013. Plankton dynamics under different climate conditions in tropical freshwater systems (a reply 
to the comment by Sarmento, Amado \& Descy, 2013). Freshwater Biology, 58 (10): 2211-2213.

DUARTE, C. M., S. AGUSTI \& N. S. R. AGAWIN. 2000. Response of a Mediterranean phytoplankton community to increased nutrient inputs: a mesocosm experiment. Marine Ecology Progress Series, 195: 61-70.

ELLIOTT, J. A. \& L. DEFEW. 2011. Modelling the response of phytoplankton in a shallow lake (Loch Leven, UK) to changes in lake retention time and water temperature. Hydrobiologia, 681 (1): 105-116.

ELLIOTT, J. A. 2011. Is the future blue-green? A review of the current model predictions of how climate change could affect pelagic freshwater cyanobacteria. Water Research, 46 (5): 1364-1371.

ELMGREN, R. \& U. LARSSON. 2001. Nitrogen and the Baltic Sea: Managing Nitrogen in Relation to Phosphorus. The Scientific World, 1: 371-377.

FARIA, D. M., L. D. S. CARDOSO \& D. MOTTA MARQUES. 2015. Periphytic diatoms exhibit a longitudinal gradient in a large subtropical shallow lake. Inland Waters, 5 (2): 117-124.

FEUCHTMAYR, H., B. MOSS, I. HARVEY, R. MORAN, K. HATTON, L. CONNOR \& D. ATKINSON. 2010. Differential effects of warming and nutrient loading on the timing and size of the spring zooplankton peak: an experimental approach with hypertrophic freshwater mesocosms. Journal of Plankton Research, 32 (12): 1715-1725.

FRAGOSO, C. R., D. M. L. MOTTA MARQUES, T. F. FERREIRA, J. H. JANSE \& E. H. VAN NES. 2011. Potential effects of climate change and eutrophication on a large subtropical shallow lake. Environmental Modelling and Software, 26 (11): 1337-1348.

FREITAS-TEIXEIRA, L. M., J. E. BOHNENBERGER, L. R. RODRIGUES, U. H. SCHULZ, D. MOTTA-MARQUES \& L.O. CROSSETTI. 2016. Temporal variability determines phytoplankton structure over spatial organization in a large shallow heterogeneous subtropical lake. Inland Waters, 6 (3): 325-335.
FUENTES, E. V. \& M. M. PETRUCIO. 2015. Water level decrease and increased water stability promotes phytoplankton growth in a mesotrophic subtropical lake. Marine and Freshwater Research, 66 (8): 711-718.

GOMES, A. M. da A., M. M. MARINHO, M. MESQUITA, A. PRESTES, M. LÜRLING \& S.M.F. de O. AZEVEDO. 2017. Warming and Eutrophication Effects on Phytoplankton Community of Two Tropical Systems with Different Trophic States - An Experimental Approach. Preprints, 2017050030. DOI: 10.20944/preprints201705.0030.v1

GUO, C., G. ZHU, B. QIN, Y. ZHANG, M. ZHU, H. XU, Y. CHEN \& H. W. PAERL. 2019. Climate exerts a greater modulating effect on the phytoplankton community after 2007 in eutrophic Lake Taihu , China: Evidence from 25 years of recordings. Ecological Indicators, 105: 82-91.

HAVENS, K. E., G. J I, J.R. BEAVER, R. S. FULTON \& C. E. TEACHER. 2017. Dynamics of cyanobacteria blooms are linked to the hydrology of shallow Florida lakes and provide insight into possible impacts of climate change. Hydrobiologia, 1-17.

HAVENS, K. E., R. S. FULTON, J. R. BEAVER, E. E. SAMPLES \& J. COLEE. 2016. Effects of climate variability on cladoceran zooplankton and cyanobacteria in a shallow subtropical lake. Journal of Plankton Research, 38 (3): 418-430.

HAVENS, K. \& E. JEPPESEN. 2018. Ecological Responses of Lakes to Climate Change. Water, 10:917.

HILLEBRAND, H., D. KIRSCHTEL, U. POLLINGHER \& T. ZOHARY. 1999. Biovolume calculation for pelagic and benthic microalgae. Journal of Phycology, 35: 403-424.

IPCC. 2007. Climate Change. 2007: Impacts, Adaptation and Vulnerability. Contribution of Working Group II to the Fourth Assessment Report of the Intergovernmental Panel on Climate Change. M. L. Parry, O. F. Canzian, J. P. Palutikof, P. J. van der Linden, and C. E. Hanson (eds.). Cambridge University Press.

JEPPESEN, E., B. KROVANG, M. MEERHOFF, M. SØNDERGAARD, K. M. HANSEN, H. E. ANDERSEN, T. L. LAU- 
RIDSEN \& L. LIBORIUSSEN. 2009. Climate Change Effects on Runoff, Catchment Phosphorus Loading and Lake Ecological State, and Potentil Adaptations. Journal of Environmental Quality, 38: 1930-1941.

JEPPESEN, E., B. MOSS, H. BENNION, L. CARVALHO, L. DEMEESTER, H. FEUCHTMAYR, N. FRIBERG, M. O. GESSNER, M. HEFTING, T. L. LAURIDSEN, L. LIBORIUSSEN, H.J. MALMQUIST, L. MAY, M. MEERHOFF, J. S. OLAFSSON, M. B. SOONS \& J. T. A. VERHOEVEN. 2010. Climate Change Impacts on Freshwater Ecosystems Interaction of climate change and eutrophication. M. Kernan, R. W. Batterbee, and B. Moss (eds.). Wiley-Blackwell. Oxford.

JEPPESEN, E., B. KRONVANG, J. E. OLESEN, J. AUDET, M. SØNDERGAARD, C. C. HOFFMANN, H. E. ANDERSEN, T. L. LAURIDSEN, L. LIBORIUSSEN, S. E. LARSEN, M. BEKLIOGLU, M. MEERHOFF, A. ÖZEN \& K. ÖZKAN. 2011. Climate change effects on nitrogen loading from cultivated catchments in Europe: implications for nitrogen retention, ecological state of lakes and adaptation. Hydrobiologia, 663 (1): $1-21$.

JÖHNK, K. D., J. HUISMAN, J. SHARPLES, B. SOMMEIJER, P. M. VISSER \& J. M. STROOM. 2008. Summer heatwaves promote blooms of harmful cyanobacteria. Global Change Biology, 14 (3): 495-512.

KOSTEN, S., V. L. M. HUSZAR, E. BÉCARES, L. S. COSTA, E. VAN DONK, L. A. HANSSON, E. JEPPESEN, C. KRUK, G. LACEROT, N. MAZZEO, L. DE MEESTER, B. MOSS, M. LÜRLING, T. NÕGES, S. ROMO \& M. SCHEFFER. 2012. Warmer climates boost cyanobacterial dominance in shallow lakes. Global Change Biology, 18 (1): 118-126.

KOTTEK, M., J. GRIESER, C. BECK, B. RUDOLF \& F. RUBEL. 2006. World Map of the Köppen-Geiger climate classification updated. Meteorologische Zeitschrift, 15 (3): 259-263.

LEWIS, W. M. J. 1983. A Revised Classification of Lakes Based on Mixing. Canadian Journal of Fisheries and Aquatic Sciences, 40:
1779-1787.

LIMA, M. S., D. DA MOTTA MARQUES, N. H. THEY, K. D. MCMAHON, L. R. RODRIGUES, L. de S. CARDOSO \& L. O. CROSSETTI. 2016. Contrasting factors drive within-lake bacterial community composition and functional traits in a large shallow subtropical lake. Hydrobiologia, 778 (1): 105-120.

LUND, J., C. KIPLIN \& E. LECREN. 1958. The Inverted Microscope Method of Estimating Algal Numbers and the Statistical Basis of Estimations by Counting. Hydrobiologia, 11: 143-170.

MACKERETH, F., J. HERON \& J. TALLING. 1989. Water analysis: some revised methods for limnologists.

MONCHAMP, M. E., P. SPAAK, I. DOMAIZON, N. DUBOIS, D. BOUFFARD \& F. POMATI. 2018. Homogenization of lake cyanobacterial communities over a century of climate change and eutrophication. Nature Ecology and Evolution, 2 (2): 317-324.

MOSS, B., D. MCKEE, D. ATKINSON, S. COLLINGS, J. W. EATON, A. B. GILL, I. HARVEY, K. HATTON, T. HEYES \& D. WILSON. 2003. How important is climate? Effects of warming, nutrient addition and fish on phytoplankton in shallow lake microcosms. Journal of Applied Ecology, 40: 782-792.

MOSS, B. 2011. Allied attack: climate change and eutrophication. Inland Waters, 1 (2): 101-105.

NEWCOMBE, G., I. CHORUS, I. FALCONER \& T. LIN. 2012. Cyanobacteria: Impacts of climate change on occurrence, toxicity and water quality management. Water Research, 46 (5): 1347-1348.

PADILLA-GAMIÑO, J. L. \& R. C. CARPENTER. 2007. Thermal ecophysiology of Laurencia pacifica and Laurencia nidifica (Ceramiales, Rhodophyta) from tropical and warm-temperate regions. Journal of Phycoly, 43 (4): 686-692.

PADISÁK, J., L. O. CROSSETTI \& L. NASELLI-FLORES. 2009. Use and misuse in the application of the phytoplankton functional classification: A critical review with updates. Hydrobiologia, 621 (1): 1-19. 
PAERL, H. \& J. HUISMAN. 2008. Blooms Like It Hot. Science, 320: 57.

PAERL, H. \& J. HUISMAN. 2009. Climate change: a catalyst for global expansion of harmful cyanobacterial blooms. Environmental Microbiology Reports, 1 (1): 27-37.

PASTERNAK, A., H. HILLEBRAND \& S. FLÖDER. 2009. Competition between benthic and pelagic microalgae for phosphorus and light - Long-term experiments using artificial substrates. Aquatic Sciences, 71 (2): 238-249.

REYNOLDS, C. S. 1998. What factors influence the species composition of phytoplankton in lakes of different trophic status? Hydrobiologia, 369/370: 11-26.

REYNOLDS, C., V. HUSZAR, C. KRUK, L. NASELLI \& S. MELO. 2002. Towards a functional classification of the freshwater phytoplankton. Journal of Plankton Research, 24 (5): 417-428.

REYNOLDS, C. S. 2006. The Ecology of Phytoplankton. Cambridge University Press. Cambridge, UK.

RIBEIRO, G. F., R. D. R. ANDRADE, C. R. M. MAIZONAVE \& L. O. CROSSETTI. 2012. Effects of cyanobacterial summer bloom on the phytoplankton structure in an urban shallow lake, Guaíba Lake, southern Brazil. Neotropical Biology and Conservation, 7 (2): 78-87.

RICHARDSON, J. A., H. FEUCHTMAYR, C. MILLER, P. HUNTER, S. C. MABERLY \& L. CARVALHO. 2019. The response of cyanobacteria and phytoplankton abundance to warming, extreme rainfall events and nutrient enrichment. Global Change Biology. DOI: 10.1111/gcb.14701

RODRIGUES, L. R., N. F. FONTOURA \& D. da MOTTA-MARQUES. 2014. Food-web structure in a subtropical coastal lake: how phylogenetic constraints may affect species linkages. Marine and Freshwater Research, 65: 453-465.

RODRIGUES, L. R., D. DA MOTTA MARQUES \& N. F. FONTOURA. 2015. Fish community in a large coastal subtropical lake: How an environmental gradient may affect the structure of trophic guilds. Limnetica, 34
(2): 495-506.

ROSA, L. M. da, L. de S. CARDOSO, L. O. CROSSETTI \& D. DA MOTTA-MARQUES. 2017. Spatial and temporal variability of zooplankton-phytoplankton interactions in a large subtropical shallow lake dominated by non-toxic cyanobacteria. Marine and Freshwater Research, 68 (2): 226

ROSENZWEIG, C., G. CASASSA, D. J. KAROLY, A. IMESON, C. LIU, A. MENZEL, S. RAWLINS, T. L. ROOT, B. SEGUIN \& P. TRYJANOWSKI. 2007. Assessment of observed changes and responses in natural and managed systems. In: Climate Change 2007: Impacts, Adaptation and Vulnerability. Contribution ofWorking Group II to the Fourth Assessment Report of the Intergovernmental Panel on Climate Changee, M.L. Parry, O.F. Canziani, J.P. Palutikof, P.J. van der Linden and C.E. Hanson. Cambridge (ed.): 79-131. Cambridge University Press. UK.

SHANNON, C. \& W. WEAVER. 1964. A Mathematical Theory of Communication. University of Illinois Press.

SMAYDA, T. \& C. S. REYNOLDS. 2001. Community assembly in marine phytoplankton: application of recent models to harmful dinoflagellate blooms. Journal of Plankton Research, 23 (5): 447-461.

SMITH, V. H., G. D. TILMAN \& J. C. NEKOLA. 1999. Eutrophication: impacts of excess nutrient inputs on freshwater, marine, and terrestrial ecosystems. Environmental pollution (Barking, Essex: 1987) 100 (1-3): 179-96.

UTERMÖHL, H. 1958. Zur Ver vollkommnung der quantitativen Phytoplankton-Methodik. Verhandlungen der Internationalen Vereinigung für Theoretische und Angewandte Limnologie, 9: 1-38.

VERDONSCHOT, P. F. M., B.M. SPEARS, C. K. FELD, S. BRUCET, H. KEIZER-VLEK, A. BORJA, M. ELLIOTT, M. KERNAN \& R. K. JOHNSON. 2013. A comparative review of recovery processes in rivers, lakes, estuarine and coastal waters. Hydrobiologia, 704 (1): 453-474.

WEYHENMEYER, G. A., R. ADRIAN, U. 
GAEDKE, D. M. LIVINGSTONE \& S. C. MABERLY. 2002. Response of phytoplankton in European lakes to a change in the North Atlantic Oscillation. Verhandlungen des Internationalen Verein Limnologie, 28: 1436-1439. WINDER, M. \& U. SOMMER. 2012. Phytoplankton response to a changing climate.
Hydrobiologia, 698, Issue 1, pp 5-16

WOODWARD, G., D. M. PERKINS \& L. E. BROWN. 2010. Climate change and freshwater ecosystems: impacts across multiple levels of organization. Philosophical transactions of the Royal Society of London. Series B. Biological sciences, 365 (1549): 2093-106.
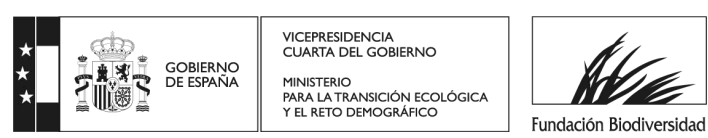